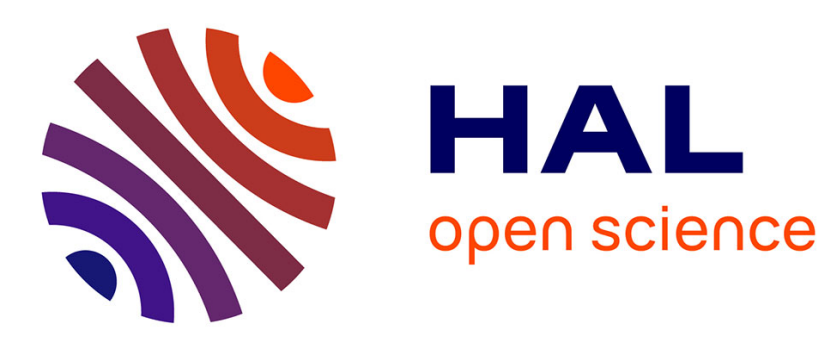

\title{
Uptake and metabolization of dissolved compounds in rainbow trout (Salmo gairdneri R.) fry
}

\author{
Benoit Fauconneau, Sadasivam Kaushik, J.M. Blanc
}

\section{To cite this version:}

Benoit Fauconneau, Sadasivam Kaushik, J.M. Blanc. Uptake and metabolization of dissolved compounds in rainbow trout (Salmo gairdneri R.) fry. Comparative Biochemistry and Physiology - A: Comparative Physiology, 1989, 93 (4), pp.839-843. 10.1016/0300-9629(89)90509-4 . hal-02728081

\section{HAL Id: hal-02728081 https://hal.inrae.fr/hal-02728081}

Submitted on 2 Jun 2020

HAL is a multi-disciplinary open access archive for the deposit and dissemination of scientific research documents, whether they are published or not. The documents may come from teaching and research institutions in France or abroad, or from public or private research centers.
L'archive ouverte pluridisciplinaire HAL, est destinée au dépôt et à la diffusion de documents scientifiques de niveau recherche, publiés ou non, émanant des établissements d'enseignement et de recherche français ou étrangers, des laboratoires publics ou privés. 


\title{
UPTAKE AND METABOLIZATION OF DISSOLVED COMPOUNDS IN RAINBOW TROUT (SALMO GAIRDNERI R.) FRY
}

\author{
Benot Fauconneau, Sadasivam J. Kaushik and Jean Marie Blanc \\ Fish Nutrition Unit, INRA, Hydrobiological Research Station, St Pée sur Nivelle B.P. 3, \\ 64310 Ascain, France. Telephone: 99-28-50-02
}

(Received 13 January 1989)

\begin{abstract}
The uptake and metabolic utilization of glucose (GL), acctate (AC), leucine (LE) and glutamic acid (GA) was studied in trout fry (mean body weight: $2.6 \mathrm{~g}$ ) by the measurement of radioactivity in soluble fraction of fish and in ${ }^{14} \mathrm{CO}_{2}$ excreted by fish after immersion of fish in a $10 \mathrm{mM}$ solution of one of these labelled $\left[\mathrm{U}-{ }^{14} \mathrm{C}\right]$ substrates.

2. The rate of intake of glucose (GL) by the fish was higher than that of AC, LE and GA (respectively, 4.6, 2.4, 2.7 and $2.1 \mu \mathrm{mol} / \mathrm{g} / \mathrm{hr}$ ). The rate of oxidation of $\mathrm{GL}$ and GA was however lower than that of $\mathrm{AC}$ and LE (respectively, $0.021,0.016,0.033$ and $0.030 \mu \mathrm{mol} / \mathrm{g} / \mathrm{hr}$ ).

3. The excretion of ammonia and urea was stimulated by the immersion in $10 \mathrm{mM}$ solution of LE or GA.

4. The oxidative metabolism of tetraploid trout did not differ from that of triploids and diploids. However, it seemed that in tetraploids oxidation of glucose was lower and oxidation of leucine respectively higher than that of other groups.
\end{abstract}

\section{INTRODUCTION}

The assessment of nutrient utilization and metabolism of fish larvae and juveniles using labelled compounds is not easy as compared to large fish. Previous works on the measurement of protein metabolism in fish larvae have suggested that it will be possible to give labelled compounds by direct immersion of fish in a solution containing these compounds (Fauconneau, 1984). In fact, as it is the case in marine invertebrates (Rice and Stephens, 1987) it seems that at early stage of ontogenesis, eggs and larvae were able to withdraw dissolved compounds from their environment (Sibers and Rosenthäl, 1976). The respective contribution of such a process and the endogenous (vitellus) and exogenous supply of nutrients (by feeding) in the covering of larvae requirement is a question that is always open. The aim of that work was to test if juveniles also possess the ability to withdraw labelled compounds and if this can be used to analyse metabolism of young fish. The present work reports uptake of some compounds involved in energy metabolism of fish and compared their rate of metabolism with those already obtained in large fish.

This was realized in trout fry of varying ploidy: diploids, triploids and tetraploids. Triploid salmonids are now produced on a large scale and the characterization of these fish, and especially their metabolism, is currently in progress (Benfey and Sutterlin, 1984; Oliva-Teles and Kaushik, 1986). Triploids are obtained either from normal diploid eggs using a heat shock after fertilization (Chourrout, 1980) or from

Correspondence should be addressed to B. Fauconneau, Fish Physiology Unit, INRA Campus de Beaulieu, avenue du Général Leclerc, 35042 Rennes Cedex, France. cross-breeding of diploid and tetraploid broodstocks (Chourrout, 1982).

\section{MATERIALS AND METHODS}

Polyploid trout were obtained as follows: a pooled sample of eggs of different diploid females were fertilized by sperm coming from different diploid males (group 2N). Duplicate samples of eggs were submitted to a heat shock during fertilization to obtain triploid trouts (group 3ND). Another pooled sample of eggs of diploid females was fertilized by sperm coming from the first generation of different tetraploid males (Chourroul, 1982) (group 3NT). Duplicate samples of these eggs were submitted to a heat shock during fertilization to obtain second "generation" tetraploids (group $4 \mathrm{~N}$ ). The growth of fish of these different families was analysed by a progeny test under experimental conditions (St Pée sur Nivelle, SW of France). Fish used in this experiment $(2.6 \mathrm{~g} \mathrm{BW})$ were sampled in batches constituted by some selected families. The mean temperature of water at the time of the experiment was $12^{\circ} \mathrm{C}$.

On the day of the experiment, triplicate groups of four fish were constituted from each major group (2N, 3ND, $3 N T$ and 4 N) I hr after the meal. Fish were transferred into tightly closed glass jars (for more details see Fauconneau, 1984) filled with a solution containing a tracer level of the labelled substrate: glucose- $\left[\mathrm{U}-{ }^{14} \mathrm{C}\right]$, acetate- $\left[\mathrm{U}-{ }^{14} \mathrm{C}\right.$, Leucine- $\left[\mathrm{U}-{ }^{14} \mathrm{C}\right]$ or glutamate- $\left[\mathrm{U}-{ }^{14} \mathrm{C}\right]$ and the same nonlabelled compound at a concentration of $10 \mathrm{mM}$. The composition of the solution was exactly: $400 \mathrm{ml}$ of water, $10-20 \mu \mathrm{Ci}$ of labelled substrate, $4 \mathrm{mmol}$ of the same unlabelled substrate, $20 \mathrm{mg}$ of streptomycine and $20 \mathrm{mg}$ of penicillin. The $\mathrm{pH}$ of the solution was adjusted to 7.0 with sodium hydroxide. The jars were thermoregulated at a mean temperature of $16.5^{\circ} \mathrm{C}$ to stimulate the metabolism of fish. The water was continuously aerated with $\mathrm{CO}_{2}$-free air. The $\mathrm{CO}_{2}$ excreted by fish in the air was collected by bubbling outlet air in a solution of $1 \mathrm{~N}$ sodium hydroxide. Fish were left in the jars for $4 \mathrm{hr}$. At the end of the experiment, the fish were removed from the jars, the water was acidified with hydrochloric acid $(6 \mathrm{~N})$ and the remaining $\mathrm{CO}_{2}$ in the water 
Table 1. Characteristics of trout fry used in this experiment (for more details see Materials and Methods)

\begin{tabular}{lcccc}
\hline & $\begin{array}{c}\text { Diploids } \\
(2 \mathrm{~N})\end{array}$ & $\begin{array}{c}\text { Triploids } \\
(3 \mathrm{ND})\end{array}$ & $\begin{array}{c}\text { Triploids } \\
(3 \mathrm{NT})\end{array}$ & $\begin{array}{c}\text { Tetraploids } \\
(4 \mathrm{~N})\end{array}$ \\
\cline { 2 - 4 } $\begin{array}{l}\text { Mean body weight } \\
(\mathrm{g})\end{array}$ & 2.5 & 2.5 & 2.4 & 2.0 \\
$\begin{array}{l}\text { Specific growth rate } \\
(\% / \text { day) }\end{array}$ & $(0.7)$ & $(0.3)$ & $(0.4)$ & $(0.3)$ \\
$\begin{array}{l}\text { Mean nuclear erythrocyte } \\
\text { volume }\left(\mu \mathrm{m}^{3}\right)\end{array}$ & 3.1 & 3.3 & 3.2 & 3.2 \\
\hline
\end{tabular}

* Mean body weight of trout used in leucine and glucose experiment ( 4 months).

+ Specific growth rate of trout during the last month preceding the experiment.

values in parentheses are SDs.

was trapped in a new solution of I $\mathrm{N}$ sodium hydroxide for 2 further hours. The radioactivity of water was measured on aliquot samples at the beginning and at the end of the experiment. The radioactivity of the two solutions of sodium hydroxide was measured. The ammonia and urea content of water was measured (see Oliva-Teles and Kaushik, 1987).

The fish were generously rinsed with distilled water then they were frozen and stored $\left(-20^{\circ} \mathrm{C}\right)$ until analysis. Free amino acids were extracted by four successive treatments (homogenization and centrifugation) with trichloracetic acid $(10 \% \mathrm{v} / \mathrm{v})$. Then lipids were extracted from TCA-insoluble residue by one acetate/methanol $(150 \mathrm{~g} / \mathrm{l} ; \mathrm{pH} 7.0)$ treatment and two successive methanol/dichloromethane $(2 v / l v)$ treatments. Then the residue was washed with ethanol and dried with ether to obtain the protein extract. The total radioactivity of TCA-soluble supernatant and of protein extract was measured (for details, see Fauconneau, 1984). The TCA-soluble extract was neutralized with sodium hydroxide and the individual amino acids were separated and detected after OPA derivatization (Hogan et al. . 1982) by HPLC (VARIAN-5000). Glucose was also measured in TCAsoluble extract using glucose-oxidase (Glucose analyser, Beckmann).

In other fishes of the same batches, blood samples were taken to obtain blood smears. After drying and staining the mean nuclear erythrocyte length and width were measured to assess mean nuclear volume.

\section{RESULTS}

\section{The performance of triploids}

Growth and the mean body weight at 3 months of age were not significantly different from that of diploids. The mean body weight of tetraploids was however $25 \%$ lower than that of other groups (Table 1). The mean nuclear erythrocyte volume was significantly higher in triploids and tetraploids than in diploids, but it was not significantly different between triploids of the 3NT groups and tetraploids.

After immersion of fish in the labelled solution for $4 \mathrm{hr}$, the apparent loss of radioactivity in the solution was higher when the substrate involved was glucose than when it was another compound (Table 2). However, radioactivily collected in acid-soluble extract, in protein extract and in $\mathrm{CO}_{2}$ excreted by fish was lower with glucose than that with acetate and leucine but close to that obtained with glutamate (Fig. 1). The resulting specific activity (S.A.) of the substrate, $4 \mathrm{hr}$ after the immersion, was not very different to that of external medium for leucine and glutamate: respectively $110 \%$ and $140 \%$ of S.A. of external medium.

The radioactivity excreled by fish as $\mathrm{CO}_{2}$ was reported to specific activity of external medium to assess the apparent rate of oxidation of the different substrates (Table 2). For acetate, the rate of production of ${ }^{14} \mathrm{CO}_{2}$ was corrected to take into account that the two carbons are labelled. The apparent rate of oxidation of leucine was not significantly different from that of acetate. The apparent rate of oxidation of glucose and glutamate was significantly lower than that of leucine and acetate. The immersion of fish in a $10 \mathrm{mM}$ solution of leucine and glutamic acid stimulated significantly the excretion of ammonia by fish when compared to that observed with glucose and acetate (Table 2).

The apparent rates of oxidation of the different substrates in diploid, triploid and tetraploid trout were not significantly different from each other (Table 3). However, in tetraploids, the oxidation of glucose was slightly lower and that of amino acids higher than that of diploids and triploids

Table 2. Utilization and oxidation of some substrates after immersion of trout in $10 \mathrm{mM}$ solution of labelled $\left(\mathrm{U}^{14} \mathrm{C}\right)$ substrate. Values were expressed as means (with $\mathrm{SD}$ in parentheses)

\begin{tabular}{lcccc}
\hline & $\begin{array}{c}\text { Glucose } \\
(n=12)\end{array}$ & $\begin{array}{c}\text { Acetate } \\
(n=12)\end{array}$ & $\begin{array}{c}\text { Leucine } \\
(n=12)\end{array}$ & $\begin{array}{c}\text { Glutamate } \\
(n=3)\end{array}$ \\
\hline Mean body weight $(\mathrm{g})$ & 2.1 & 3.2 & 2.6 & 2.8 \\
& $(0.3)$ & $(0.7)$ & $(0.5)$ & $(0.3)$ \\
Molarity of solution & 10.7 & 9.8 & 10.0 & 9.8 \\
$\quad(\mathrm{mM})$ & $(0.02)$ & $(0.01)$ & $(0.01)$ & $(0.01)$ \\
Specific activity of solution & 4.2 & 3.9 & 5.3 & 2.1 \\
$\quad(\mu \mathrm{Ci} / \mathrm{mmol})$ & $(0.1)$ & $(0.1)$ & $(0.2)$ & $(0.7)$ \\
Intake of substrate from the & 4.6 & 2.4 & 2.7 & 2.1 \\
the solution $(\mu \mathrm{mol} / \mathrm{g} \mathrm{BW} / \mathrm{hr})$ & $(2.8)$ & $(0.9)$ & $(0.9)$ & $(0.4)$ \\
Apparent oxidation of substrate & 0.021 & 0.030 & 0.033 & 0.016 \\
$\quad(\mu \mathrm{mol} / \mathrm{g} \mathrm{BW} / \mathrm{hr})$ & $(0.006)$ & $(0.003)$ & $(0.010)$ & $(0.001)$ \\
Ammonia excretion & 1.3 & 2.0 & 11.3 & 5.7 \\
$\quad(\mu \mathrm{mol} / \mathrm{g} \mathrm{BW} / \mathrm{hr})$ & $(0.3)$ & $(0.3)$ & $(2.3)$ & $(0.6)$ \\
Urea excretion & 0.3 & 0.5 & 0.7 & 0.5 \\
$(\mu \mathrm{mol} / \mathrm{g} \mathrm{BW} / \mathrm{hr})$ & $(0.4)$ & $(0.1)$ & $(0.1)$ & $(0.1)$ \\
\hline
\end{tabular}


Table 3. Oxidation of some substrates in polyploid trout after immersion in $10 \mathrm{mM}$ solution of these labelled (U. ${ }^{14} \mathrm{C}$ ) substrates (in $\mathrm{nmol} / \mathrm{g} \mathrm{BW} / \mathrm{hr}$ ) expressed as means (with SD in parentheses) (for more details see Materials and Methods)

\begin{tabular}{|c|c|c|c|c|c|c|}
\hline & \multirow[b]{2}{*}{$\begin{array}{c}\text { Glucose } \\
(n=3) \\
a\end{array}$} & \multirow[b]{2}{*}{$\begin{array}{c}\text { Acetate } \\
(n=3) \\
b\end{array}$} & \multirow[b]{2}{*}{$\begin{array}{c}\text { Leucine } \\
(n=3) \\
c\end{array}$} & \multirow[b]{2}{*}{$\begin{array}{c}\text { Cilutamate } \\
(n=1) \\
\mathrm{d}\end{array}$} & \multicolumn{2}{|c|}{ Ratios } \\
\hline & & & & & $\begin{array}{c}\text { LEU/GLU } \\
\mathrm{c} / \mathrm{a}\end{array}$ & $\begin{array}{c}\text { GLUT/ACET } \\
\mathrm{d} / \mathrm{b}\end{array}$ \\
\hline Tetraploids $(4 N)$ & $\begin{array}{l}15.6 \\
(2.8)\end{array}$ & $\begin{array}{l}27.4 \\
(1.9)\end{array}$ & $\begin{array}{c}41.3 \\
(13.7)\end{array}$ & 17.6 & 2.6 & 0.6 \\
\hline Triploids (3NT) & $\begin{array}{l}25.2 \\
(4.5)\end{array}$ & $\begin{array}{l}32.8 \\
(3.9)\end{array}$ & $\begin{array}{l}33.4 \\
(9.7)\end{array}$ & 14.6 & 1.3 & 0.4 \\
\hline Triploids (3ND) & $\begin{array}{l}20.5 \\
(9.5)\end{array}$ & $\begin{array}{l}29.2 \\
(2.2)\end{array}$ & $\begin{array}{l}26.8 \\
(3.4)\end{array}$ & 15.3 & 1.3 & 0.5 \\
\hline Diploids (2N) & $\begin{array}{l}24.1 \\
(5.3)\end{array}$ & - & $\begin{array}{c}30.7 \\
(11.1)\end{array}$ & - & 1.3 & - \\
\hline
\end{tabular}

$3 \mathrm{NT}$ triploids obtained from $2 \mathrm{~N} \times 4 \mathrm{~N}$.

$3 \mathrm{ND}$ triploids obtained from $2 \mathrm{~N} \times 2 \mathrm{~N}$ and heat shock.

\section{DISCUSSION}

\section{Validity of the method}

When fish were immersed in a solution containing trace amounts of a labelled substrate (arginine), this substrate was absorbed by fish and the specific activity of this compound in the body fluids of fish stabilized within a few hours $(2-4 \mathrm{hr}$ ) (Fauconneau, 1984; Fauconneau et al., 1986a, b). The substrate is absorbed by fish through different means: gills, digestive tract and skin. Toxicological studies have demonstrated that in fish there are two mechanisms of intake of a substrate through the gill: an aqueous transport for low molecular weight compounds controlled by aqueous diffusion rate through the gills, and a transport for polar compounds which might be dependent on membrane lipids (McKim et al, 1985). It has been shown that some metabolites (glucose) which could be excreted through the gill are actively

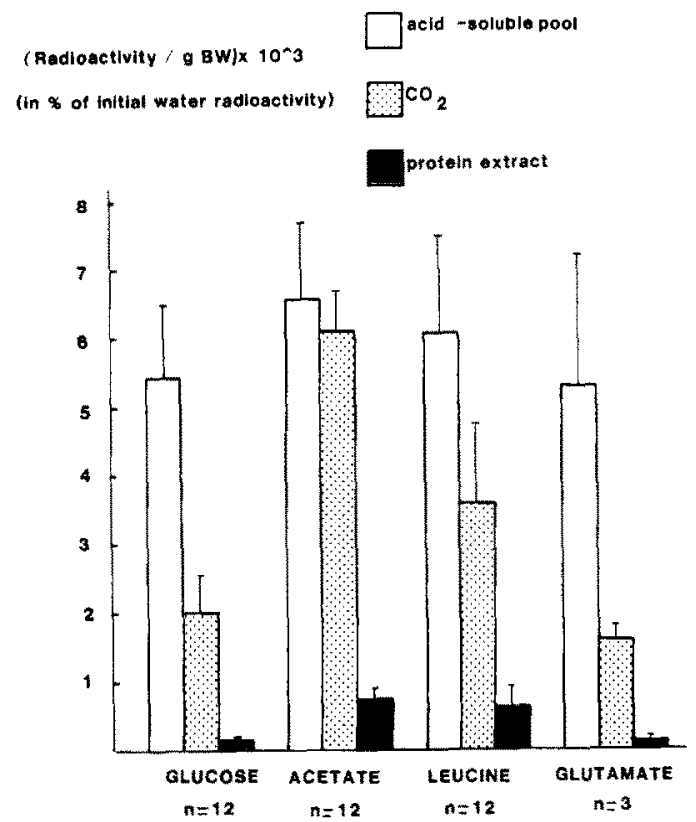

Fig. 1. Radioactivity collected in different fractions of fish (acid-soluble pool and protein extract) and in $\mathrm{CO}_{2}$ excreted by fish after its immersion in $10 \mathrm{mM}$ solution of some selected substrate (in \% of initial radioactivity in the solution $/ \mathrm{g}$ of fish $\left.\times 10^{3}\right)$. reabsorbed by chloride cells (Furspan and Isaia, 1983). This capacity of substrate reabsorption by the gill could facilitate the intake of a labelled compound into the fish. It seemed, however, that this capacity decreases with age (Fauconneau et al., 1986a). Furthermore, if fish were immersed in a solution containing a labelled compound and a large amount of the same non-labelled substrate, the specific activity of this substrate into the fish could be altered in a manner close to that of the external medium. It has been demonstrated that when osmolarity of external media increases, the gill osmotic water permeability also increases (Parker et al., 1985). In this experiment, the specific activity of amino acids into the fish assessed $4 \mathrm{hr}$ after the immcrsion of fish into the labelled solution was close to that of the external solution. This confirmed, at least for amino acid, the validity of the method. In fact, the oxidation rate of glucose and leucine were in the same range of those reported in the literature, respectively: $80-100 \mathrm{nmol} / \mathrm{hr} / \mathrm{g} \mathrm{BW}$ (Garin and Demael, 1979) and $44-45 \mathrm{nmol} / \mathrm{hr} / \mathrm{g} \mathrm{BW}$ (Fauconneau and Arnal, 1985). The rate of utilization of different substrates in the perfused hind parts of rainbow trout were, however, lower than that observed in this experiment (Moen and Klungsoyr, 1981).

The rate of oxidation of glutamate was lower than that of other substrates, probably related to the lower specific activity of glutamate in the external solution than that of other substrates (Table 2).

The stimulation of ammonia excretion in fish immersed in a $10 \mathrm{mM}$ solution of amino acid could be related to an alteration of gill exchange. Ammonia excretion through the gill is considered to be essentially a passive phenomenon. However, excretion of $\mathrm{NH}_{4}^{+}$is associated with excretion of $\mathrm{CO}_{2}$ in the carbonate form in order to control ionic homeastasis (Maetz, 1972). Thus, intake of amino acid through the gill could be associated with ammonia excretion by a simple mechanism of exchange through the gill.

\section{Comparative utilization of different substrates}

The rate of oxidation of glucose was lower than that of acetate and amino acids such as alanine, glutamic acid and even leucine. This has been demonstrated in carnivorous fish: plaice, turbot, sea bass and trout (Cowey, 1975; Cowey and Sargent, 1979; Garin and Mockry, 1982; Van den Thillart, 1986) and in omnivorous fish such as carp (Nagai and Ikeda, 
1972, 1973; Zebian and Creach, 1979). The rate of utilization of glucose in vivo in fish is low when compared to that of the rat (Lin et al., 1978; Garin and Demael, 1979). Results obtained by assessment of nitrogen budget demonstate that a large proportion of dietary amino acids are used for energetic purposes (Cho and Kaushik, 1985) and this contribution has been quantified for leucine (Fauconneau and Arnal, 1985) and for arginine (Fauconneau, 1984; Fauconneau et al, 1986a, b). During fasting, and in catabolic states, non-essential as well as essential amino acids are used for oxidative metabolism in preference to glucose (Creach, 1972; Zebian and Creach, 1979; Van den Thillart, 1986). According to Rumsey (1981), amino acid catabolism in physiological conditions is not controlled in fish by amounts of available substrate. The present work confirmed that rate of utilization of glucose was low when compared to that of acetate and amino acids such as leucine. It has been demonstrated that perfused hind part of trout, metabolized glucose better than amino acids (Moen and Klungsoyr, 1981), White muscle of fish seems to have high glycolytic capacity (Jones and Sidell, 1982). The utilization of glucose by the cells could be limited by the intake of glucose. In fact, the injection of insulin in vivo increases the intake and utilization of glucose by the muscle (Moen and Klungsoyr, 1980). It appears that the utilization of glucose is more under hormonal than metabolic control. It is also worth mentioning that white muscle which is the main tissue of fish $(50-60 \%$ body weight), has a lower metabolic activity than that of other tissue such as liver, digestive tract and gills (Fauconneau and Arnal, 1985; Houlihan et al., 1986), and these tissues actively catabolize most of the amino acids. Thus, it can be suggested that the control of oxidative metabolism by regulatory organs such as those previously mentioned is more important in fish than in mammals and consequently, the utilization of substrate such as amino acid is facilitated. When substrate supply increases (in diet or through the gills), the role of these organs increases.

The fact that oxidation of glutamate in this experiment was lower than that of leucine could also be explained as an effect of toxicity due to an excess of glutamate. When it is supplied in large amounts by the diet it has been suspected that glutamate is not well used (Hughes, 1985) something comparable to the toxicity of glutamate observed in humans and mammals.

\section{Influence of polyploidy}

In this experiment the increase in the nuclear size of erythrocytes in tetraploids compared to triploids of the same origin is not as important as that of triploids compared to diploids. Thus, with a limit in the increase in the size of the cells, the metabolism of the cells could be altered. In fact, it seems that polyploidy has few consequences in terms of oxidative catabolism. Many works demonstrated that in trout, metabolism of triploids is not significantly different from that of diploids (Benfey and Sutterlin, 1984; Oliva-Teles and Kaushik, 1986). Balance studies have shown that there are no differences between these four groups (2N, 3ND, 3NT and 4N) in the metabolic utilization of dietary protein and energy (Oliva-Teles and Kaushik, 1987). In this experiment, if tetraploids seems to have a lower body weight than triploids and diploids, as it has been demonstrated in the progeny test (Blanc, in preparation), the specific growth rate of tetraploids at 3 months seemed not to be significantly different when compared to that of diploids and triploids. Furthermore, in tetraploid trouts, the rate of oxidation of leucine was slightly higher and that of glucose, respectively, slightly lower than in other groups. It could be a consequence of the bad capacity of adaptation of tetraploids to the experimental procedure which stimulates oxidative metabolism.

\section{REFERENCES}

Benfey T. J. and Sutterlin A. M. (1984) Oxygen utilization by triploid landlocked atlantic salmon (Salmo salar L.). Aquaculture 42, 69-73.

Cho C. Y. and Kaushik S. J. (1985) Effects of protein intake on metabolizable and net energy values of fish diets. In Nutrition and Fish Feeding (Edited by Cowey C. B., Mackie A. M. and Bell J. G.), pp. 95-118. Acad. Press, London.

Chourrout D. (1980) Thermal induction of diploid gynogenesis and triploidy in the eggs of the rainbow trout (Salmo gairdneri Richardson). Reprod. Nutr. Dev. 20, 727-801.

Chourrout D. (1982) Tetraploidy induced by heat shocks in the rainbow troul (Salmo gairdnerii R.). Reprod. Nutr. Dev. 22, 569-574.

Cowey C. B. (1975) Aspects of protein utilization by fish. Proc, Nutr. Soc. 34, 57-63.

Cowey C. B. (1985) Biological assessment of nutrient requirements and availability in fish. Utilization of energetic substances. In Proceedings XIII International Congress of Nutrition (Edited by Taylor T. G. and Jenkins N. K.), pp. 896-898. John Libbey, London.

Cowey C. B. and Sargent J. R. (1979) Nutrition. In Fish Physiology Bioenergetics and Growth (Edited by Hoar W. S., Randall J. R. and Brett J. R.), Vol. 8, pp. 1-79. Academic Press, London.

Cowey C. B., Knox D., Walton M, J, and Adron J. W (1977) The regulation of gluconeogenesis by diet and insulin in rainbow trout (Salmo gairdneri) Br. J. Nutr. 38, 463-470.

Creach Y. (1972) Le jeûne expérimental chez la capre: métabolisme azoté et équilibre hydrominéral. Doct. Sci. Thesis, Univ Toulouse.

Fauconneau B. (1984) The measurement of whole body protein synthesis in larval and juvenile carp (Cyprinus carpio). Comp. Biochem. Physiol. 78B, 845-850.

Fauconneau B. and Arnal M. (1985) Leucine metabolism in trout (Salmo gairdnerii R.). Influence of temperature. Comp. Biochem. Physiol. 82A, 435-445.

Fauconneau B., Aguirre P. and Bergot P. (1986a) Protein synthesis in early life of coregonids: influence of temperature and feeding, Arch. Hydrobiol. Beih. Ergebn. Limnol. 22, $171-188$

Fauconneau B., Aguirre P., Dabrowski K. and Kaushik S. J. (1986b) Rearing of sturgeon (Acipenser baeri Brandt) larvae 2 Protein metabolism: influence of fasting and diet quality, Aquaculture 51, 117-131.

Furspan P. and Isaia J. (1983) Glucose transport across the gill of the rainbow trout, Salmo gairdneri. Comp. Biochem. Physiol. 75A, 401-406.

Furuichi $M$. and Yone $Y$. (1982) Effect of insulin on blood sugar levels of fishes. Bull. Jpn Soc. Scient. Fish. 48, $1289-1291$.

Garin D. and Demael A. (1979) Métabolismes glucidiques et intermediaire. In La Nutrition des Poissons (Edited by 
Fontaine M.), pp. 185-213. Les éditions du C.N.R.S., Paris.

Garin D. and Mockry M. (1982) Etude de l'utilisation énergetique de substrate aminés, glucidiques et lipidiques. Influence de la carnitine et du phosphate alimentaire sur la neoglucogénese et l'utilisation des acides gras. Rapport CNEXO No. 82-2687, Editions IFREMER, Paris.

Hilton J. W. and Atkinson J. L. (1982) Response of rainbow trout (Salmo gairdneri) to increased levels of available carbohydrate in practical trout diets. Br. J. Nutr. 47, $597-607$.

Hogan D. L., Kraemer K. L. and Isenberg J. I. (1982) The use of high-performance liquid chromatography for quantitation of plasma amino acids in man. Anal. Biochem. 127, 17-24.

Houlihan D., McMillan D. M. and Laurent P. (1986) Growth rates, protein synthesis and protein degradation rates in rainbow trout: cffects of body' size. Rhysiol. Zool. 59, $482-493$.

Hughes S. G. (1985) Evaluation of glutamic acid and glycine as sources of non essential amino acids for lake trout (Salvelinus namaycush) and rainbow trout (Salmo gairdnerii). Comp. Biochem. Physiol. 81, 669-671.

Jones P. L. and Sidell B. D. (1982) Metabolic responses of striped bass (Morone saxatilis) to temperature acclimation. II. Alterations in metabolic carbon sources and distributions of fiber types in locomotory muscle. J. exp. Zool. 219, 163-171

Lin H., Romsos D. L., Tack P. L. and Leveille G. A. (1978) Determination of glucose utilization in coho salmon (Oncorhynchus kisutch Walbaum) with [6-3H]- and [U-14C]-glucose. Comp. Biochem. Physiol. 59A, 189-191.

Maetz J. (1982) Branchial sodium exchange and ammonia excretion in the goldfish Carassius auratus. Effects of ammonia loading and temperature changes. J. exp. Biol. 56, 601-620.

McKim J., Schmieder P. and Veith G. (1985) Absorption dynamics of organic chemical transport across trout gills as related to octanol-water partition coefficient. Toxicol. appl. Pharmacol. 77, 1-10.

Moen, K. A. and Klungsoyr L. (1981) Metabolism of exogenous substrates in perfused hind parts of rainbow trout Salmo gairdnerii. Comp. Biochem. Physiol. 68B, 461-466.
Nagai M. and Ikeda S. (1972) Carbohydrate metabolism in fish. Effect of dietary composition on metabolism of glucose-[U-14C] and glutamate-[U-14C] in carp. Bull. Jpn Soc. Sci. Fish. 38, 137-143.

Nagai M. and Ikeda S. (1973) Carbohydrate metabolism in fish. Effect of dietary composition on metabolism of acetate-[U-14C] and L-alanine-[U-14C) in carp. Bull. Jpn Soc. Sci. Fish. 39, 633-644.

Oliva-Teles A. and Kaushik S. J. (1986) Nitrogen and energy metabolism during the early ontogeny of diploid and triploid rainbow trout (Salmo gairdneri R.) Comp. Biochem. Physiol. 87A, 157-160.

Oliva-Teles A. and Kaushik S. J. (1987) The metabolic utilization of diets by polyploid rainbow trout (Salmo gairdneri R.). Comp. Biochem. Physiol. 88A, 45-47.

Parker D. B., McKeown B. A. and MacDonald J. S. (1985) The effect of $\mathrm{pH}$ and/or freshwater on Gill $\mathrm{Ca}^{2+}$ ATPasc activity and osmotic factor inflow in rainbow trout (Salmo gairdneri). Comp. Biochem. Physiol. 79A, 149-156.

Rice M. A. and Stephens G. C. (1987) Uptake and internal distribution of exogeneously supplied amino acids in the Pacific Oyster, Crassostea gigas (Thunberg). Aquaculture 66, 19-31.

Rumsey G. L. (1981) Significance of nitrogen metabolism: why does the salmonid require a high protein diet. Salmonid 5, 20-24.

Siebers D. and Rosenthal H. (1977) Amino acid absorption by developing herring eggs. Helgol. Wiss. Meeresunters 29, 464-472.

Van den Thillart G. (1986) Energy metabolism of swimming trout (Salmo gairdneri). Oxidation rates of palmitate, glucose, lactate, alanine, leucine and glutamate. $J$. comp. Physiol. 156, 511-520.

Walton M. J. and Cowey C. B. (1982) Aspects of intermediary metabolism in salmonid fish. Comp. Biochem. Physiol. 73A, 59-79.

Zebian M. F. and Creach Y. (1979) Fraction alpha-aminée libre et dégradation oxydative de quelques acides aminés chez la carpe (Cyprinus carpio L.). In Finfish Nutrition and Fishfeed Technology (Edited by Halver J. E. and Tiews K.), Vol. 2, pp. 531-544. Heinemann, Berlin. 